\title{
Genetics of Grain Yield and its Components in Wheat under Heat Stress
}

\author{
S. Sareen ${ }^{1 *}$, N. Bhusal ${ }^{1}$, G. Singh ${ }^{2}$, B.S. Tyagi ${ }^{1}$, V. Tiwari ${ }^{1}$, G.P. Singh ${ }^{1}$ and A.K. SARIAL ${ }^{2,3}$ \\ ${ }^{1}$ ICAR-Indian Institute of Wheat and Barley Research, Karnal (Haryana) India \\ ${ }^{2}$ Department of Genetics and Plant Breeding, CCS Haryana Agricultural University, \\ College of Agriculture Campus Kaul, Kaithal 136021 Haryana India \\ ${ }^{3}$ Vice-Chancellor, CSK Himachal Pradesh KrishiVishvaVidyalaya, Palampur 176062 Himachal Pradesh India
}

(Received 25 December 2017; Accepted 9 February 2018;

Communicated by M. Taylor)

\begin{abstract}
Heat stress is a matter of a great concern for the wheat crop. Heat stress usually either hastens crop development or shortens the grain filling duration, which severely reduces grain yield. Being a complex trait, understanding the genetics and gene interactions of stress tolerance are the two primary requirements for improving yield levels. Genetic analysis through generation mean analysis helps to find out the nature of gene actions involved in a concerned trait by providing an estimate of main gene effects (additive and dominance) along with their digenic interactions (additive $\times$ additive, additive $\times$ dominance, and dominance $\times$ dominance). In the present investigation, we elucidated the inheritance pattern of different yield contributing traits under heat stress using different cross combinations which could be helpful for selecting a suitable breeding strategy. Thus six generations of five crosses were sown normal (non-stress, TS) and late (heat stress, LS) in a randomized block design with three replications during two crop seasons. The model was not adequate for late sown conditions indicating the expression of epistatic genes under stress conditions. The traits i.e. Days to heading (DH), Days to anthesis (DA), Days to maturity (DM), Grain filling duration (GFD), Grain yield (GY), Thousand grain weight (TGW), Grain weight per spike (GWS) and Heat susceptibility index (HSI) under heat stress conditions were found under the control of additive gene action with dominance $\times$ dominance interaction, additive gene action with additive $\times$ dominance epistatic effect, dominance gene action with additive $\times$ additive interaction effect, additive and dominance gene action with dominance $\times$ dominance interaction effect, additive gene action with additive $\times$ dominance epistatic effect, additive gene action with additive $\times$ additive interaction effect and dominance gene action with additive $\times$ additive interaction effect, respectively.
\end{abstract}

Keywords: heat stress, wheat, genetics, generation mean analysis

\section{Introduction}

Heat stress is a matter of great concern in wheat growing areas throughout the world under climate change scenarios. In India, it affects approximately $13.5 \mathrm{~m}$ ha area which covers the central and peninsular area as well as late sowings in other parts of the country

*Corresponding author; E-mail: Sindhu.Sareen@icar,gov.in 
(Joshi et al. 2007). About 20\% yield losses in wheat in certain pockets of the Indo Gangetic Plains is due to a $2{ }^{\circ} \mathrm{C}$ increase in seasonal temperatures (Lobell et al. 2012). Heat stress usually hastens crop development and shortens the grain filling duration, which severely reduces the grain yield in wheat.

Understanding the genetics and gene interaction of stress tolerance are primary requirements for crop improvement. The elucidation of the genetic basis of these traits under heat stress conditions will enhance the efficiency of wheat improvement programmes targeted to develop heat tolerant cultivars. Biometrical techniques used for genetic analysis and pattern of inheritance are helpful to the plant breeder in selecting the improved genotypes for different environments and production systems (Poodineh and Rad 2015). Genetic analysis through generation mean analysis helps to find out the nature of gene actions involved in a concerned trait by providing an estimate of the main gene effects (additive and dominance) along with their digenic interactions (additive $\times$ additive, additive $\times$ dominance, and dominance $\times$ dominance). It has been previously shown that inheritance of plant height, biological yield, grain yield, number of kernels/spike, 100-kernel weight, number of spikes/plant under heat stress were associated with both additive and non-additive genetic components of variance (Abd-Allah et al. 2013; Ahmad et al. 2016). While, non-additive and over-dominance types of gene action were reported for days to heading, spike length, biological yield and grain yield (Ljubičić et al. 2014; Al-Layla 2015; Kandil et al. 2016), additive effects with partial dominance were reported for earliness, tillers per plant, plant height, spike length and grain yield (Farooq et al. 2010; El-Rahman 2013; Nazir et al. 2014) and dominance and dominance $\times$ dominance epistatic effects for grain yield (Fethi 2010). In the present investigation, we explained the inheritance pattern of different yield contributing traits under heat stress using different cross combinations which could be helpful for adopting suitable breeding strategies.

\section{Material and Methods}

Out of eight genotypes evaluated for terminal heat stress tolerance under field and temperature controlled conditions during three crop seasons, 2007-2010, crosses were attempted between three heat tolerant and the three heat susceptible genotypes during 2010-2011 crop season (Table 1). The parents along with $\mathrm{F}_{1 \mathrm{~s}}$ were sown during the season 2011-2012 to produce $\mathrm{F}_{2}$ (selfing of some of the $\mathrm{F}_{1}$ plants) and backcross $\left(\mathrm{BC}_{1}\right.$ and

Table 1. Pedigree details of genotypes used in the study for generation mean analysis in wheat

\begin{tabular}{|c|l|l|l|l|}
\hline Sr. No & Genotypes & \multicolumn{1}{|c|}{ Pedigree } & \multicolumn{1}{c|}{$\begin{array}{c}\text { Remarks } \\
\text { Crosses used } \\
\text { in present investigation }\end{array}$} \\
\hline 1 & K7903 & HD 1982/ K 816 & Heat tolerant & C1(K7903 X RAJ 4088) \\
\hline 2 & RAJ4088 & & Heat susceptible & C2(K7903 X P11632) \\
\hline 3 & P11632 & & Heat susceptible & C3(HD2808 X P11632) \\
\hline 4 & HD2808 & WH 542/DL 377-8 & Heat tolerant & C4(HD2808 X HUW510) \\
\hline 5 & HUW510 & HD 2278/ HUW 234// DL 230-16 & Heat susceptible & C5(RAJ 4014 XHUW510) \\
\hline 6 & RAJ4014 & DL 8025/K 9011 & Heat tolerant & \\
\hline
\end{tabular}


$\mathrm{BC}_{2}$ ) generations. Thus six populations $\mathrm{P}_{1}, \mathrm{P}_{2}, \mathrm{~F}_{1}, \mathrm{~F}_{2}, \mathrm{BC}_{1}$ and $\mathrm{BC}_{2}$ derived from five crosses were sown under two conditions, normal (non-stress, TS) and late sown (heat stress, LS) in a randomized block design with three replications at the experimental farm of the Indian Institute of Wheat and Barley Research (IIWBR), Karnal during crop seasons 2012-2013 and 2013-2014. The normal or non-stress sowing (TS) was done during mid-November and late or stress sowing (LS) was done during mid-December. Plot size consisted of two rows each of parents, $\mathrm{F}_{1}, \mathrm{BC}_{1}$ and $\mathrm{BC}_{2}$ and ten rows of $\mathrm{F}_{2}$ populations. Row length was $1 \mathrm{~m}$ with $23 \mathrm{~cm}$ spacing between rows. Data were recorded on five randomly selected plants each of parents, $\mathrm{F}_{1}, \mathrm{BC}_{1}$ and $\mathrm{BC}_{2}$ and 10 plants of $\mathrm{F}_{2}$ generation.

Plants were scored for phenological and grain yield and its components viz; days to heading (DH), days to anthesis (DA), days to maturity (DM), grain filling duration (GFD), grain weight per spike (GWS), thousand grain weight (TGW) and grain yield/plant (GY). GWS was determined from the main spike of marked plants. GY was measured after harvesting, threshing, and cleaning of the marked plants at maturity. Heat susceptibility index (HSI) was calculated for each generation of each cross following the formula, given by Fischer and Maurer (1978).

$$
\mathrm{HSI}=[1-(\mathrm{Ys} / \mathrm{Yt}) /(1-\mathrm{Xs} / \mathrm{Xt})]
$$

Where Ys is the grain yield under stress (late sown), Yt is the grain yield under non-stress (normal sown), Xs and Xt are the mean yield of all generations of the cross under stress and non-stress conditions, respectively.

\section{Statistical analysis}

Tests for scale effects were computed following the methods explained by Mather (1949) and Hayman and Mather (1955). Estimation of different gene effects in the interacting crosses was done using six parameter (Hayman 1958) and three parameter (Jinks and Jones 1958) models. The mean effects of the A, B, C and D models were estimated as

$$
\begin{aligned}
& \mathrm{A}=2 \overline{\mathrm{BC}} 1-\overline{\mathrm{P}} 1-\overline{\mathrm{F}} 1 \\
& \mathrm{~B}=2 \overline{\mathrm{BC}} 2-\overline{\mathrm{P}} 2-\overline{\mathrm{F}} 1 \\
& \mathrm{C}=4 \overline{\mathrm{F}} 2-2 \overline{\mathrm{F}} 1-\overline{\mathrm{P}} 1-\overline{\mathrm{P}} 2 \\
& \mathrm{D}=\overline{\mathrm{F}} 2-\overline{\mathrm{BC}} 1-\overline{\mathrm{BC}} 2
\end{aligned}
$$

The variances of different scale effects were calculated as follows:

$$
\begin{aligned}
& \mathrm{VA}=4 \mathrm{~V}(\overline{\mathrm{BC}} 1)+\mathrm{V}(\overline{\mathrm{P}} 1)+\mathrm{V}(\overline{\mathrm{F}} 1) \\
& \mathrm{VB}=4 \mathrm{~V}(\overline{\mathrm{BC}} 2)+\mathrm{V}(\overline{\mathrm{P}} 2)+\mathrm{V}(\overline{\mathrm{F}} 1) \\
& \mathrm{VC}=16 \mathrm{~V}(\overline{\mathrm{F}} 2)+4 \mathrm{~V}(\overline{\mathrm{F} 1})+\mathrm{V}(\overline{\mathrm{P}} 1)+\mathrm{V}(\overline{\mathrm{P}} 2) \\
& \mathrm{VD}=4 \mathrm{~V}(\overline{\mathrm{F} 2})+\mathrm{V}(\overline{\mathrm{BC}} 1)+\mathrm{V}(\overline{\mathrm{BC}} 2)
\end{aligned}
$$


To test the adequacy of an additive-dominance model for each cross, the standard errors of $\mathrm{A}, \mathrm{B}, \mathrm{C}$ and $\mathrm{D}$ were obtained by taking the square root of their respective variance. $T$-test values were calculated by dividing the effects of the respective standard errors.

Generation means were analyzed using the 'joint scaling test' proposed by Cavalli (1952). The Hayman (1958) six-parameter model was used for estimations of various genetic components. According to Hayman (1958); $\mathrm{m}=$ mean effect, $\mathrm{d}=$ additive effects for all the loci, $\mathrm{h}=$ dominance effects for all the loci, $\mathrm{i}=$ digenic interactions among the homozygous combinations (additive $\times$ additive gene action), $\mathrm{j}=$ digenic interactions among the pair of homozygous and heterozygous combinations (additive $\times$ dominance gene action) and $1=$ digenic interactions among the heterozygous combinations (dominance $\times$ dominance gene action). The mean effects of all six parameters were estimated as

$$
\begin{aligned}
& \mathrm{m}=\overline{\mathrm{F} 2} \\
& \mathrm{~d}=\overline{\mathrm{BC}} 1-\overline{\mathrm{BC}} 2 \\
& \mathrm{~h}=\overline{\mathrm{F} 1}-\overline{\mathrm{F} 2}-0.5(\overline{\mathrm{P} 1})-0.5(\overline{\mathrm{P} 2})+2(\overline{\mathrm{BC} 1})+2(\overline{\mathrm{BC}} 2) \\
& \mathrm{i}=2(\overline{\mathrm{BC}} 1)+2(\overline{\mathrm{BC}} 2)-4(\overline{\mathrm{F} 2}) \\
& \mathrm{j}=(\overline{\mathrm{BC}} 1)-0.5(\overline{\mathrm{P}} 1)-(\overline{\mathrm{BC}} 2)+0.5(\overline{\mathrm{P}} 2) \\
& \mathrm{l}=(\overline{\mathrm{P}} 1)+(\overline{\mathrm{P}} 2)+2(\overline{\mathrm{F}} 1)+4(\overline{\mathrm{F}} 2)-4(\overline{\mathrm{BC}} 1)-4(\overline{\mathrm{BC}} 2)
\end{aligned}
$$

The variance of each gene action was obtained as:

$$
\begin{aligned}
& \mathrm{Vm}=\mathrm{V}(\overline{\mathrm{F}} 2) \\
& \mathrm{Vd}=\mathrm{V}(\overline{\mathrm{BC}} 1)-\mathrm{V}(\overline{\mathrm{BC}} 2) \\
& \mathrm{Vh}=\mathrm{V}(\overline{\mathrm{F} 1})-16 \mathrm{~V}(\overline{\mathrm{F} 2})-0.25 \mathrm{~V}(\overline{\mathrm{P} 1})-0.25 \mathrm{~V}(\overline{\mathrm{P} 2})+4 \mathrm{~V}(\overline{\mathrm{BC} 1})+4 \mathrm{~V}(\overline{\mathrm{BC}} 2) \\
& \mathrm{Vi}=4 \mathrm{~V}(\overline{\mathrm{BC}} 1)+4 \mathrm{~V}(\overline{\mathrm{BC}} 2)-16 \mathrm{~V}(\overline{\mathrm{F} 2}) \\
& \mathrm{Vj}=\mathrm{V}(\overline{\mathrm{BC}} 1)-0.25 \mathrm{~V}(\overline{\mathrm{P}} 1)-\mathrm{V}(\overline{\mathrm{BC}} 2)+0.25 \mathrm{~V}(\overline{\mathrm{P}} 2) \\
& \mathrm{V} 1=\mathrm{V}(\overline{\mathrm{P}} 1)+\mathrm{V}(\overline{\mathrm{P}} 2)+4 \mathrm{~V}(\overline{\mathrm{F}} 1)+16 \mathrm{~V}(\overline{\mathrm{F}} 2)-16 \mathrm{~V}(\overline{\mathrm{BC}} 1)-16 \mathrm{~V}(\overline{\mathrm{BC}} 2)
\end{aligned}
$$

The standard error of $h, d, i, j$ and 1 was obtained by taking the square root of their respective variance. Heritability, GCV, PCV of the crosses were estimated using software SPAR 2.0. 


\section{Results}

\section{Heat stress}

The post heading stage showed average minimum and maximum temperature under normal sown conditions as 12.29 and $27.04{ }^{\circ} \mathrm{C}(2012-2013)$ and 10.16 and $22.89{ }^{\circ} \mathrm{C}(2013-$ 2014) while, under late (stress) sown conditions it was recorded 15.97 and $32.81{ }^{\circ} \mathrm{C}$ (2012-2013) and 12.44 and $26.94{ }^{\circ} \mathrm{C}$ (2013-2014), respectively (Figure S1*).

\section{Analysis of variance and mean performance}

Pooled analysis of variance indicated that all the crosses and generations differed significantly for all the traits under LS (stress) conditions (Table S1). The interaction between crosses and generations was significant for all the traits except for TGW. The $\mathrm{F}_{1}$ mean values exceeded the mid values of the two parental means for most of the studied traits under TS (non-stress) and LS (stress) conditions. HSI of $\mathrm{F}_{1}$ was high in all the crosses than mid-parental value except for C2 during 2012-2013 and C3 and C4 during 20132014, respectively (Fig. 1). The mean performance of $F_{2}$ populations recorded higher values for most of the studied traits than parents and $F_{1}$ means.

\section{Scaling test and gene effects}

Days to heading

The scaling test was significant for all the crosses under LS (stress conditions). Scale A, $\mathrm{B}, \mathrm{C}$ and D in C4, scale A, B, and C in C5, scale A, C and D in C3, scale B, C and D in $\mathrm{C} 2$ and $\mathrm{C} 4$, and scale $\mathrm{A}$ and $\mathrm{C}$ in $\mathrm{C} 1$ was found significant. It was significantly associated with positive additive main effect in $\mathrm{C} 1, \mathrm{C} 2, \mathrm{C} 3$, and $\mathrm{C} 5$ and positive dominance effect in $\mathrm{C} 3$ and negative dominance effect in $\mathrm{C} 1$ and $\mathrm{C} 2$. It showed all types of interaction effects in $\mathrm{C} 2$, additive $\times$ additive and additive $\times$ dominance effect in $\mathrm{C} 1$, additive $\times$ dominance and dominance $\times$ dominance effect in $\mathrm{C} 5$ and dominance $\times$ dominance effect in $\mathrm{C} 3$ and $\mathrm{C} 4$ under stress condition (Table S2). Under TS it was associated with dominance main effect in $\mathrm{C} 1, \mathrm{C} 2, \mathrm{C} 4$, and $\mathrm{C} 5$, and the additive main effect in $\mathrm{C} 2$ and $\mathrm{C} 4$.

\section{Days to anthesis}

Days to anthesis was found to be significant in all scaling tests. Scale A, B and C in C5, scale $\mathrm{B}, \mathrm{C}$ and $\mathrm{D}$ in $\mathrm{C} 2$, scale $\mathrm{A}$ and $\mathrm{C}$ in $\mathrm{C} 1$ and $\mathrm{C} 3$, and scale $\mathrm{B}$ and $\mathrm{C}$ in $\mathrm{C} 4$, was found to be significant. Under LS conditions gene effects for DA were associated with main additive effects in $\mathrm{C} 2, \mathrm{C} 3$, and $\mathrm{C} 5$ while the main dominance effect was found significant in $\mathrm{C} 2$. Additive $\times$ additive, additive $\times$ dominance and dominance $\times$ dominance in $\mathrm{C} 2$, additive $\times$ dominance and dominance $\times$ dominance in $\mathrm{C} 5$ and additive $\times$ dominance interaction effects in $\mathrm{C} 1$ were found to be significant. Under TS conditions the main additive

*Further details about the Electronic Supplementary Material (ESM) can be found at the end of the article. 

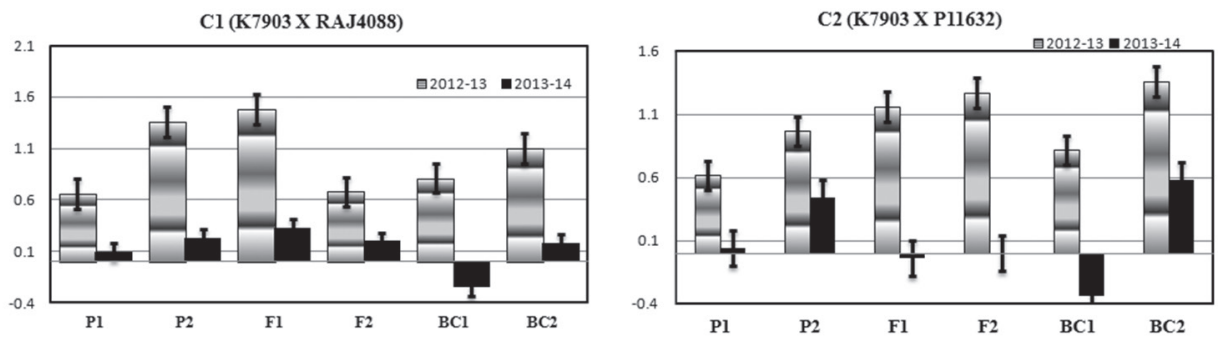

C3 (HD2808 X P11632)
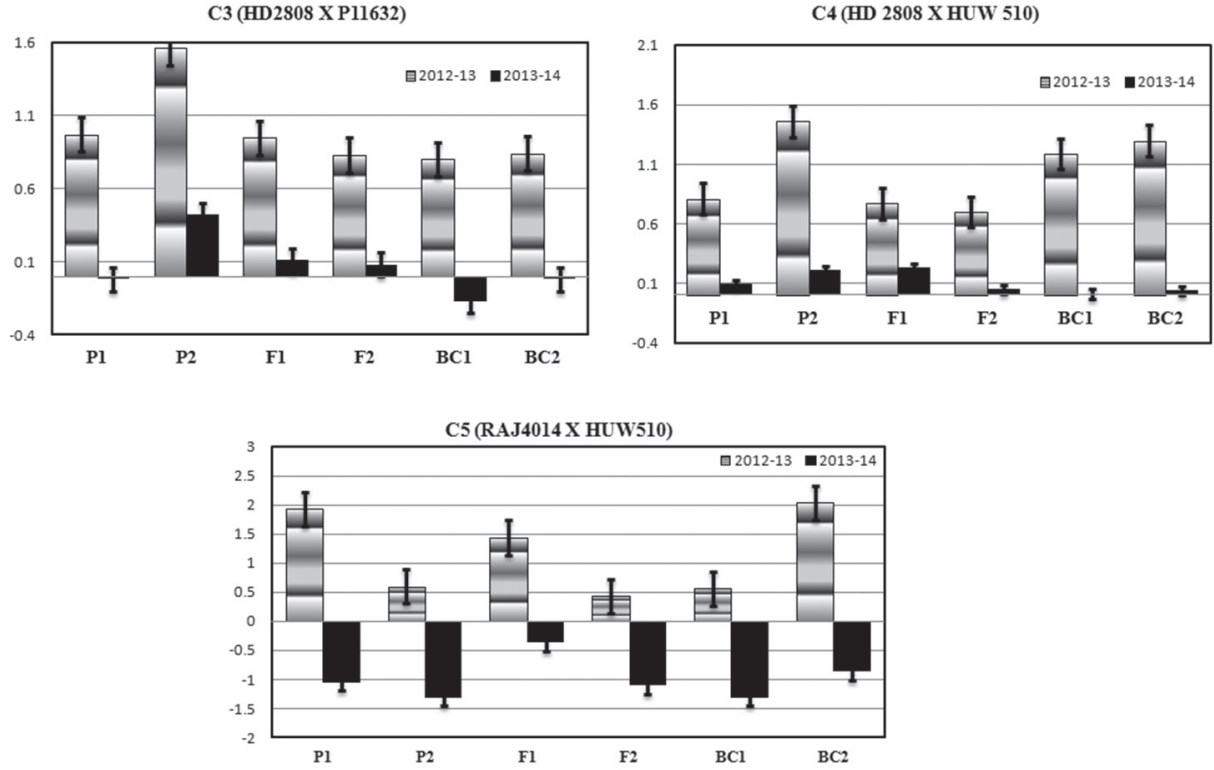

Figure 1. Heat susceptibility index of different crosses of wheat during 2012-2013 and 2013-2014

effect was found to be significant in $\mathrm{C} 2$ and $\mathrm{C} 5$ and dominance effect in $\mathrm{C} 1, \mathrm{C} 2, \mathrm{C} 3$ and $\mathrm{C} 5$.

\section{Days to maturity}

Scale C and D in C2, C3, and C5 and scale B in C1 was found significant (Table S2). Gene effects for DM under LS conditions showed significant main dominance effects in all the crosses except $\mathrm{C} 5$. There were additive $\times$ additive interaction effects in $\mathrm{C} 2, \mathrm{C} 3$, and $\mathrm{C} 4$ and a dominance $\times$ dominance effect in $\mathrm{C} 1$. Under TS conditions an additive-dominance model was found to show the best fit. 


\section{Grain filling duration}

Scaling tests for grain filling duration showed the significance of scale $\mathrm{A}, \mathrm{B}$ and $\mathrm{C}$ in $\mathrm{C}$, scale $\mathrm{B}, \mathrm{C}$ and $\mathrm{D}$ in $\mathrm{C} 2$, and scale $\mathrm{A}$ and $\mathrm{C}$ in $\mathrm{C} 1$, while in the remaining crosses an additive-dominance model was found to show the best fit. Gene effects under LS conditions showed significant additive and dominance main effects with all types of interaction effects in $\mathrm{C} 2$, additive main with additive $\times$ dominance and dominance $\times$ dominance interaction effects in $\mathrm{C} 5$ and dominance main and dominance $\times$ dominance interaction effects in $\mathrm{C} 4$ (Table S2). Under TS conditions there were additive and dominance main effects with additive $\times$ additive interaction in $\mathrm{C} 2$ and $\mathrm{C} 5$, dominance main effect in $\mathrm{C} 3$ and $\mathrm{C} 1$.

\section{Grain yield/plant}

An additive-dominance model in $\mathrm{C} 5$ was found to show the best fit, while the remaining crosses showed significance in scaling tests. Scale B, C, and D in C3, scale A and B in C2, $\mathrm{B}$, and $\mathrm{C}$ in $\mathrm{C} 4$, scale $\mathrm{A}$ in $\mathrm{C} 1$ and scale $\mathrm{C}$ in $\mathrm{C} 3$ was found significant. Grain yield/plant under late sown conditions was associated with significant additive main effects in $\mathrm{C} 1$ and $\mathrm{C} 2$ while it was associated with additive $\times$ additive and additive $\times$ dominance interaction effects in $\mathrm{C} 3$, additive $\mathrm{x}$ dominance interaction effect in $\mathrm{C} 2$ and $\mathrm{C} 4$ (Table S2). Under TS conditions GY was associated with additive main effects in C5 and dominance main effects in $\mathrm{C} 1$ and $\mathrm{C} 3$.

\section{Thousand grain weight}

An additive-dominance model was found to be fit for thousand grain weight in $\mathrm{C} 2$ and $\mathrm{C} 3$ under TS conditions (Table S2). For other crosses Scaling tests showed significance in crosses under stress conditions. Scale C and D in C5, scale A in C1, scale B in C2, and C3 and scale D in $\mathrm{C} 4$. Under LS conditions additive and dominance main effect with all types of interaction were found significant in $\mathrm{C} 2$ and additive main effect with additive $\times$ dominance interaction effect in C5. Under TS conditions additive and dominance and additive main effects with all types of epistatic interactions were found significant in $\mathrm{C} 5$ and $\mathrm{C} 1$, respectively.

\section{Grain weight main spike}

For grain weight/main spike, an additive-dominance model in $\mathrm{C} 5$ was found to show the best fit for stress conditions. Scale C and D in C4, scale A in C1 and C2, and scale B in C3 were found significant (Table S2). Gene effects for grain weight/main spike under LS conditions showed significance for additive and dominance main effects with additive $\times$ additive and dominance $\times$ dominance interaction effect in $\mathrm{C}$, additive main effect with additive $\times$ dominance effect in $\mathrm{C} 2$, additive main effect with additive $\times$ additive and additive $\times$ dominance interaction effect in $\mathrm{C} 3$ and additive $\times$ additive interaction effect in $\mathrm{C} 4$. Under TS conditions a dominance main effect was found significant in $\mathrm{C} 1, \mathrm{C} 2$, and $\mathrm{C} 4$. 


\section{Heat susceptibility index}

Scaling test of heat susceptibility index was significant in C2 and C3 during both the years, C4 during 2013-2014 and C5 during 2012-2013 while remaining crosses i.e. C1 during both the years, C4 during 2012-2013 and C5 during 2013-2014 showed the significance of B, C, and D scale (Table S2). There were significant additive main effects in $\mathrm{C} 3$ during both the years while there were dominance main effects with additive $\times$ additive interaction effects in C1 during both the years, C4 during 2012-2013 and C5 during 2013-2014.

\section{Genetic parameters and Heritability}

High GCV and low PCV were recorded for grain yield/plant in most of the studied crosses under both the conditions (Table S3). Low to moderate GCV and PCV under both the conditions were recorded for TGW and GWS while, low GCV and PCV were recorded for DH, DA, DM and GFD under TS as well as LS conditions. Heritability was higher under TS conditions than LS for the all of the crosses. Under LS conditions all the crosses and studied traits showed moderate to low level of heritability while, there was high heritability for GY and DA.These traits showed high heritability under TS conditions.

\section{Discussion}

In the present investigation, the mean minimum and maximum temperature under LS condition during the post heading period were higher than TS conditions by 3.68 and $5.77{ }^{\circ} \mathrm{C}$ during $2012-2013$ and 2.28 and $4.06{ }^{\circ} \mathrm{C}$ during $2013-2014$ crop seasons. The first and third week after post heading showed a rise in temperature to more than $30^{\circ} \mathrm{C}$ during 2012-2013 and 2013-2014, respectively indicated that both the crop seasons faced terminal heat stress.

Analysis of variance revealed significant variations among the studied traits. The $\mathrm{F}_{1}$ mean values exceeded the mid values of the two parental means for most of the studied traits under both sowing conditions indicating that these traits are under dominance control. The presence of transgressive segregants in populations was recorded for most of the traits. The recombination between the alleles at multiple loci in $\mathrm{F}_{1}$ could be the reason for transgressive segregation (Bell and Travis 2005).

Estimation of gene effects using six parameter models allows estimation of main genetic components as well as additional parameters that were necessary to specify the effects of interaction of non-allelic genes. The results revealed that generation means were significantly different for all the studied traits in all crosses. A, B, C and D scaling tests for five crosses under TS and LS conditions showed the inadequacy of an additive-dominance model for explaining the inheritance of all studied characters under both environments, indicating thereby the presence of non-allelic gene interactions or epistasis. However, this model also showed adequacy under stress for DM (C5), GFD (C3), GY (C5), GWS (C5) and HSI (C2 and C3) during both the years while, under non-stress conditions 
for DH (C1 and C5), DA (C4), DM (C2, C3 and C5), GFD (C3 and C4), GY (C4 and C5), TGW (C2 and C3) and GWS (C5) (Table S2). Non-significant effects indicated the fitness of an additive-dominance model for explaining the inheritance of these traits in respective crosses. In the present investigation, most of the traits under non-stress conditions showed the adequacy of the model while under stress conditions, it was not adequate. The expression of silent genes under stress conditions may lead to non-adequacy of the model. The traits showing the adequacy of additive-dominance models indicated these traits were under control of major genes. Similar findings were observed for TGW, GWS, and GY by earlier workers (Lal et al. 2013; Hamam 2014). However, the significant effect of scale A, $\mathrm{B}, \mathrm{C}$ and $\mathrm{D}$ recorded in almost all traits indicated that additive-dominance model is inadequate to explain the genetics of studied traits and a significant role of epistasis in their genetic control under non-stress (TS) and stress (LS) conditions.

The positive and significant magnitude of additive gene action (d) was recorded under heat stress conditions for DH, DA, GY, GWS and TGW indicating that additive gene effects in the inheritance of these traits played a significant role in respective crosses while these traits showed the negative magnitude of additive gene action under favourable conditions. Irshad et al. (2014) observed only additive (D) gene action for TGW under favourable and heat stress conditions. However, some of the crosses showed negative significance for GFD, GY under LS conditions and HSI, indicating that negative alleles were prevalent, which ultimately reduced the performance. Earlier, Saint Pierre et al. (2010) and Hamam (2013) reported negative and significant additive gene effect.

The estimate of dominance gene action (h) was found to be significant and positive for TGW, GWS and HSI under heat stress conditions. There was a significant negative magnitude for DH, DA, DM, GFD, GY under heat stress conditions which indicated the importance of dominance gene action for controlling these characters. Previously significant and positive dominance gene action was observed in kernels/spike and 100-kernel weight (Hamam 2013); biomass per plant at anthesis (Irshad et al. 2014); days to 50\% flag leaf emergence, days to anthesis, plant height, peduncle length, number of tillers per plant, number of spikelets per spike, number of grains per spike, 1000-grain weight, awn length, biological yield per plant, grain yield (Sheikh et al. 2009)

The estimates of epistatic gene effects showed additive $\times$ additive (i) epistatic gene effects giving positive effects in the expression for HSI, GFD, TGW, GWS, GY in most of the crosses under LS conditions while it showed the negative effect for DM. Under TS conditions these traits showed negative additive $\times$ additive epistatic effects. Likewise, a positive additive $\times$ dominance $(\mathrm{j})$ type of epistasis was found for DA, GY, HSI, and TGW under late sown conditions in most of the crosses. The higher dominance $\times$ dominance $(\mathrm{L})$ interactions with significant positive effects for DM, GFD and TGW and negative dominance $\times$ dominance effects for DH and GY under stress as well as non-stress conditions indicate the important role of dominance $\times$ dominance gene action in the genetic system. The similar results were reported by El-Sayed and El-Shaarawy (2006) and Hamam (2013). 


\section{Heritability and genetic parameters}

The estimates of PCV and GCV and heritability are always useful in determining the method of selection to improve a particular population for a specific trait. The PCV was greater than GCV for all the traits studied for all crosses. A high magnitude for GCV, PCV and heritability were recorded for GY, while other studied traits in the present investigation showed moderate to low GCV and PCV under both, stress as well as non-stress conditions. Degewione et al. (2013) found high PCV and GCV for grain yield per plot. Other workers have also reported high PCV and GCV for GY and TGW (Tarekenge et al. 1995; Sharma et al. 1995). Higher heritability was recorded under TS than LS conditions for all the crosses indicating that gene expressions under LS conditions were affected by heat stress. Low to moderate GCV and PCV under both the conditions over the years were recorded for TGW and GWS. However, moderate heritability under TS and LS conditions were recorded for DM, DA, GFD, and TGW, and high heritability under TS and moderate heritability under LS was recorded for DH, GWS, and GY. Previously, moderate heritability for TGW (Bhusal et al. 2016), GY (Singh et al. 2014) and high heritability for TGW and GY (Hamam 2014) has been reported under heat stress condition. The results indicated that under heat stress conditions sets of alleles and possibly the different loci are being expressed.

\section{Conclusion}

The significance of one or the other scale indicated the presence of non-allelic gene interaction while non-significance of all scales was interpreted as an adequate explanation of an additive $\times$ dominant model. This model was adequate for most of the studied traits under TS conditions, while it was not adequate for LS conditions indicating the expression of epistatic genes under stress conditions. The traits i.e. DH, DA, DM, GFD, GY and TGW, GWS and HSI under heat stress conditions were under control of additive gene action with dominance $\times$ dominance interaction effects, additive gene action with additive $\times$ dominance epistatic effects, dominance gene action with additive $\times$ additive interaction effects, additive and dominance gene action with dominance $\times$ dominance interaction effects, additive gene action with additive $\times$ dominance epistatic effects, additive gene action with additive $\times$ additive interaction effects and dominance gene action with additive $\times$ additive interaction effects, respectively. The traits with additive gene action and additive $\times$ additive interaction could be improved through the pedigree method of breeding. However, the traits having dominance gene action with additive $\times$ additive, additive $\times$ dominance, and dominance $\times$ dominance interactions effect can be harnessed through bi-parental mating and recurrent selection.

\section{Acknowledgments}

This work was supported by Indian Council of Agricultural Research, New Delhi under Institute project no. CRSCDWRSIL201001400105. 


\section{References}

Abd-Allah, M.H., Soheir, M.H., Amin, I.A. 2013. Genotypic differences for heat tolerance traits in bread wheat using five parameters genetic model. Alex. J. Agric. Res. 58(2):83-96.

Ahmad, I., Mahmood, N., Khaliq, I., Khan, N. 2016. Genetic analysis for five important morphological attributes in wheat (T. aestivum L.). J. Anim. Plant Sci. 26(3):725-730.

Al-Layla, M.J. 2015. Genetic analysis of yield and its components for wheat. Jordan J. Agric. Sci. 11(2):507524.

Bell, M.A., Travis, M.P. 2005. Hybridization, transgressive segregation, genetic co-variation, and adaptive radiation. Trends in Ecology \& Evolution 20(7):358-361.

Bhusal, N., Sarial, A.K., Saharan, R.P., Munjal, R., Meena, B.K., Sareen, S. 2016. Phenotyping of RIL population derived from heat tolerant and susceptible parents for grain yield and its components in wheat under terminal heat stress. Advances in Life Sciences 5(12):5021-5028.

Cavalli, L.L. 1952. An analysis of linkage in quantitative inheritance. In: Rieve ECR, Weddington CH, eds. Quantitative Inheritance. HMSO, London. pp. 135-144.

Degewione, A., Dejene, T., Sharif, M. 2013. Genetic variability and traits association in bread wheat (Triticum aestivum L.) genotypes. Int. Res. Jour. of Agri. Sci. 1(2):19-29.

El-Rahman, M.E.A. 2013. Estimation of some genetic parameters through generation mean analysis in three bread wheat crosses. Alex. J. Agric. Res. 58(3):183-195.

El-Sayed, E.A.M., El-Shaarawy, G.A. 2006. Genetical studies on yield and some agronomic characters in some bread wheat (Triticum aestivum L.) crosses. J. Agric. Sci. 31(8):4901-4914.

Farooq, J., Khaliq, I., Khan, A.S., Pervez, M.A. 2010. Studying the genetic mechanism of some yield contributing traits in wheat (T. aestivum L.). Int. J. Agric. Biol. 12:241-246.

Fethi, B., Mohamed, El. G. 2010. Epistasis and genotype-by-environment interaction of grain yield related traits in durum wheat. Jour. of Plant Breed. Crop Sci. 2(2):24-29.

Fischer, R.A., Maurer, R. 1978. Drought resistance in wheat cultivars I. Grain yield response. Aust. Jour. Agric. Res. 29:897-907.

Hamam, K.A. 2013. Estimation of genetic parameters using five populations model in three bread wheat crosses under normal irrigation and drought stress. In $8^{\text {th }}$ international plant breeding conference, Kafr El Sheikh University, Egypt, 14th-15th May 2013.

Hamam, K.A. 2014. Genetic analysis of agronomic traits in bread wheat using six parameters model under heat stress. Egypt J. Agron. 36(1):1-18.

Hayman, B.I. 1958. The separation of epistatic from additive and dominance variation in generation means. Heredity 12:371-390.

Hayman, B.I., Mather, K. 1955. The description of gene interaction in continuous variation. Biometrics 11:69-82.

Irshad, M., Khaliq, I., Iqbal, J., Hussain, N., Aslam, M., Hussain, K., Din, N. 2014. Genetics of some polygenic traits in hexaploid bread wheat in high temperature stress. Jour. Animal and Plant Sci. 24(4):12121219.

Jinks, J.L., Jones, R.M. 1958. Estimation of components of heterosis. Genetics 43:223-234.

Joshi, A.K., Mishra, B., Chatrath, R., Ferrara, G.O., Singh, R.P. 2007. Wheat improvement in India: present status, emerging challenges and future prospects. Euphytica 157(3):431-446.

Kandil, A..A., Sharief, A.E., Gomaa, H.S.M. 2016. Estimate of gene action for yields and its components in bread wheat (T. aestivum L.). Int. J. Agro. Agric. Res. 8(1):34-40.

Lal, C., Maloo, S.R., Kumar, V. 2013. Generation mean analysis for some heat tolerance and quantitative characters in bread wheat (Triticum aestivum L.). J. Wheat Res. 5(2):22-26.

Ljubičić, N., Petrović, S., Dimitrijević, M., Hristov, N., Vukosavljev, M., Srećkov, Z. 2014. Diallel analysis for spike length in winter wheat. Turk. J. Agric. Nat. Sci. 2:1455-1459.

Lobell, D.B., Sibley, A., Ortiz-Monasterio, J.I. 2012. Extreme heat effects on wheat senescence in India. Nature Climate Change 2(3): 186 .

Mather, K. 1949. Biometrical Genetics. Dover Press, New York, USA, London. 
Nazir, A., Khaliq, I., Farooq, J., Mahmood, K., Mahmood, A., Hussain, M., Shahid, M. 2014. Pattern of inheritance in some yield related parameters in spring wheat (T. aestivum L.). Am. J. Biol. Life Sci.2(6):180-186.

Poodineh, M., Rad, M.R.N. 2015. Genetic components for physiological parameters estimates in bread wheat (T. aestivum L.). Annu. Res. Rev. Biol. 7(3):163-170.

Saint Pierre, C., Crossa, J., Manes, Y., Reynolds, M.P. 2010. Gene action of canopy temperature in bread wheat under diverse environments. Theor. Appl. Genet. 120:1107-1117.

Sharma, D.J., Yadav, R.K., Sharma, R.K. 1995. Genetic variability and association of some yield components in winter x spring nursery of wheat. Adv. Plant Sci. 8(1):95-99.

Sheikh, S., Behl, R.K., Dhanda, S.S., Kumar, A. 2009. Gene effects for different metric traits under normal and high temperature stress environments in wheat (T. aestivum L. EmThell). The South Pacific Journal of Natural and Applied Sciences. 27(1):38-44.

Singh, G., Kulshreshtha, N., Singh, B.N., Setter, T.L., Singh, M.K., Saharan, M.S., Tyagi, B.S., Verma, A., Sharma, I. 2014. Germplasm characterization, association and clustering for salinity and waterlogging tolerance in bread wheat (Triticum aestivum). Ind. Jour. Agric. Sci. 84(9):1102-1110.

Tarekegne, A., Tanner, D.G., Tesemma, T., Gebeyehu, G.E. 1995. Improvement of durum wheat yield and associated effects on morpho-physiological characters. African Crop Science Journal. 3(4):433-442.

\section{Electronic Supplementary Material (ESM)}

Electronic Supplementary Material (ESM) associated with this article can be found at the website of CRC at https://akademiai.com/loi/0806

Electronic Supplementary Table S1. Pooled analysis of variance of various traits used to study the genetics of heat tolerance in wheat during Rabi season 2012-2013 and 2013-2014

Electronic Supplementary Table S2. Pooled scaling test and gene effects of different crosses of wheat under normal and heat stress conditions during 2012-2013 and 2013-2014

Electronic Supplementary Table S3. Estimates the GCV, PCV and Heritability (bs) of various traits in different crosses of wheat during crop season 2012-2013 and 2013-2014

Electronic Supplementary Figure S1. Post heading daily Maximum and Minimum temperature under timely and late sown conditions. A: During crop season 2012-2013, B: During crop season 2013-2014 